\title{
A Green Fluorescent Protein-actin Fusion Protein Dominantly Inhibits Cytokinesis, Cell Spreading, and Locomotion in Dictyostelium
}

\author{
Hiroyuki Aizawa, Masazumi Sameshima, and Ichiro Yahara ${ }^{\dagger}$ \\ Department of Cell Biology, The Tokyo Metropolitan Institute of Medical Science, Honkomagome 3-18-22, \\ Bunkyo-ku, Tokyo 113, Japan
}

Key words: actin/green fluorescent protein/dominant negative/cytokinesis/cell movement

\begin{abstract}
We transformed Dictyostelium discoideum cells by a vector for expression of a chimerical fusion protein consisting of Aequorea Victoria green fluorescent protein (GFP) and $D$. discoideum actin at its amino- and carboxy-terminal, respectively. The amount of expressed GFP-actin was about $3 \%$ of total actin molecules in the transformed cells. The expression of GFP-actin in D. discoideum completely inhibited cytokinesis in suspension culture. The expression decreased the rate of random cell locomotion to about a half of that of control cells. The expression also caused the cells to round up. These phenotypic observations suggested that GFPactin acts as a dominant negative form of actin in the cells. The rounding up by expression of GFP-actin was suppressed by genetical elimination of myosin II heavy chain. This result suggested that myosin II is necessary for the rounding up of GFP-actin expressing cells. GFP-actin constructed cortical actin filament architectures together with intrinsic actin in the cells. Purified GFP-actin polymerized and de-polymerized repetitively according to the solution conditions in vitro. The critical concentration of GFP-actin for polymerization is the same as that of actin. The GFP-actin filaments was able to bind to coverglass surfaces coated with myosin head fragments. However, the GFP-actin filaments did not slide at all on the coverglass by addition of ATP. This indicates that the GFP-actin filaments form rigor complex with myosin II in vitro even in the presence of ATP. The formation of rigor complex may cause the cells to round up.
\end{abstract}

The crawling movement of eukaryotic cells on the surface of substrates is divided into three processes; cell protrusion, attachment to the surface, and traction (1, $2)$. All three processes involve actin filaments $(3,4)$ which are formed by self-assembly of monomeric actin (5), and are highly organized into ultrastructures such as meshwork and bundles with the aid of various actinbinding proteins $(6,7)$. In muscle cells, there are stable contractile structures called "sarcomere" which are composed of repeating assemblies of actin and myosin II filaments (8). Such highly organized structures are not present in non-muscle cells, but there are instead contractile bundles of actin filaments and myosin II filaments such as the adhesion belt in epithelial cells, the contractile ring in dividing cells, and the stress fibers in cultured fibroblast cells $(9,10)$.

Evidence that myosin II is involved in non-muscle cell

$\dagger$ To whom correspondence should be addressed.

Tel: 81-3-3823-2101, Fax: 81-3-5685-2932

e-mail: yahara@rinshoken.or.jp

${ }^{1}$ Abbreviations used in this paper: CBB, Coomassie Brilliant Blue; DAPI, 4',6-deamidino-2-phenylindol; GFP, green fluorescent protein; HMM, heavy meromyosin; MHC, myosin II heavy chain; S1, subfragment-1; SDS, sodium dodecyl sulfate; PAGE, polyacrylamide gel electrophoresis. movement has been obtained by disruption of myosin functions in cells. Microinjection of anti-myosin II antibody into starfish blastomeres blocks cytokinesis (11). Gene disruption of the myosin II heavy chain (MHC) ${ }^{1}$ in $D$. discoideum inhibits cytokinesis in suspension culture, capping of surface receptors, rounding up by azide treatment, and cell locomotion (12-14). This evidence for loss-of-functions suggests requirement of myosin II for those cell movement processes. In non-muscle cells, there are various types of myosins as well as myosin II (15-18). Each myosin molecule consists of a globular head(s), which is/are shared with all the myosin superfamily members, and a long rod-like tail(s) specific for each myosin species. The head is a motor domain which is necessary and sufficient for sliding on actin filaments. In actively crawling cells, myosin I and myosin II localize at the forward protruding region and the backward retracting tail region, respectively (1921). Thus, myosin I and myosin II are supposed to produce power for cell protrusion and traction processes, respectively. Gene disruption of any one of myosin I molecules, however, caused only a weak phenotype (22, 23). The weak phenotype of myosin-I disruptants may be accounted for by the presence of other myosin I members which could complement the lost myosin-I func- 
tions.

In this work, we found that green fluorescent protein (GFP)-actin fusion protein acts as a dominant negative mutant of actin molecule in $D$. discoideum. The phenotypic analyses of the GFP-actin expressing cells shed light on the mechanism of actin system in cell movements.

\section{MATERIALS AND METHODS}

Cell Lines and Vectors. D. discoideum $\mathrm{Ax} 2$ cell line (clone 214; a generous gift from Dr. G. Gerisch at Max-Planck-Institute for Biochemistry, Martinsried, Germany) was maintained as previously described (24). A control vector, pEXP, was constructed as follows. An extrachromosomal shuttle vector, pBIG (25) was digested with NotI, after which the both ends were blunted by Klenow large fragment of DNA polymerase I. The plasmid was then self-ligated by T4 DNA ligase to construct a vector pBIG $\Delta$ NotI. A double strand DNA was prepared by the annealing of two synthetic oligonucleotides, BNTX1 (GATCCGCGGCCGCTAAATAAATAAC) and BNTX2 (TCGAGTTATTTATTTAGCGGCCGCG), and the DNA was ligated into a plasmid pBsr2 (26) which had been digested with $B a m H I$ and $X h o I$. The resultant plasmid was sequentially treated by HindIII, Klenow fragment, and $X b a \mathrm{I}$. The excised $0.9 \mathrm{kbp}$ fragment was ligated into the pBIG $\Delta N o t \mathrm{I}$, which had been pre-treated sequentially with $B a m H I$, Klenow fragment, and $X b a I$. The resultant extrachromosomal vector, pEXP, contains BamHI, NotI, and XhoI restriction sites between actin 15 promoter and actin 8 terminator. An expression vector for GFP, pGFP, was constructed as follows. An S65T-GFP cDNA was amplified by PCR using two synthetic oligonucleotides, GFP-F (AAATGGATCCG AGTAAAGGAGAAGAACTT) and GFP-R (AAAACTCG AGTTAGTCGACTTTGTATAGTTCATCCAT), as primers from a template plasmid containing an S65T-GFP coding sequence (a gift from Dr. R.Y. Tsien, University of California, La Jolla, CA). The amplified cDNA was digested with BamHI and $X h o I$, and ligated into pEXP which had been treated by $B a m H I$ and $X h o I$. The resultant plasmid, pGFP, expresses a S65T-GFP protein with two additional amino acid residues (Asp and Pro) just after the initiation Met and two additional amino acid residues (Val and Asp) on the carboxyl terminus. We also constructed a vector for expression of (His) ${ }_{6}$-tagged GFP, pHGFP, by using a synthetic oligonucleotide primer, HGFP-F (AAATGGATCCGCATCATCATCATCATCATA GTAAAGGAGAAGAACTT), instead of the primer GFP-F as described above. An expression vector for GFP-actin was constructed as follows. The actin 15 cDNA was amplified by PCR using two synthetic oligonucleotides ACT-F (AAAGT CGACATGGATGGTGAAGATGTTCA) and ACT-R (AAAA CTCGAGTTAGAAACATTTTCTGTGGA) as primers from a template plasmid SC79 (a gift from Dr. D.A. Knecht, University of Connecticut, Storrs, CT). The amplified cDNA was sequentially treated with Klenow fragment and SalI, and li- gated into pGFP which had been treated sequentially by XhoI, Klenow fragment, and SalI. The resultant plasmid, pGACT, contains an artificial GFP-actin fusion gene consisting of actin 15 promoter, an initiation Met codon followed by in-frame GFP-actin cDNA, and actin 8 terminator. We also constructed a vector for expression of (His) 6 -tagged GFP-actin, pHGACT, by inserting the amplified cDNA into the plasmid pHGFP instead of pGFP as described above. The resultant plasmids, pEXP, pGFP, pGACT, and pHGACT, were separately introduced into $D$. discoideum cells by electroporation and transformed cells were selected in HL5 medium containing $7 \mu \mathrm{g} / \mathrm{ml}$ neomycin as described elsewhere (24). A gene replacement vector for MHC, pMYO2: BSR, was constructed as follows. The extrachromosomal expression plasmid, pBIGmyosin (25; a gift from Dr. J.A. Spudich, Stanford University of Medicine, Stanford, CA), was treated with $A p a \mathrm{I}, X b a \mathrm{I}$, and Klenow fragment, and then self-ligated by T4 DNA ligase. The resultant plasmid was treated with $N c o$ I and Klenow fragment, and ligated with the $b s r$ gene cassette which had been excised from $\mathrm{pBsr} 2$ by treatment with $X b a \mathrm{I}$, HindIII, and Klenow fragment. The resultant plasmid, pMYO2: BSR, contains anti-directed bsr gene cassette at $N c o$ I site in the myosin-II heavy chain gene. The plasmid was digested by KpnI, and treated with T4 DNA polymerase in the presence of dGTP in order to prevent intracellular self-ligation. The fragments were introduced into cells by electroporation. Transformed cells were primarily selected in HL5 medium containing $10 \mu \mathrm{g} / \mathrm{ml}$ blasticidin S (Funakoshi Co., Tokyo, Japan). We randomly selected 24 clones. All of them did not form fruiting body under starvation stress on a filter, and failed to divide in suspension culture. The absence of MHC in the clones was confirmed by western blot analysis using rabbit antiserum directed against myosin heavy chain as described below.

Optical Microscopic Observation. Cells grown on a glass coverslip were starved in MCM buffer for $1 \mathrm{hr}$, and then fixed in MCM buffer containing $2 \%$ formaldehyde for $15 \mathrm{~min}$ at $25^{\circ} \mathrm{C}$. For staining of actin filaments, the fixed cells were incubated in PBS (10.6 mM Na $2 \mathrm{HPO}_{4}, 1.7 \mathrm{mM} \mathrm{KH}_{2} \mathrm{PO}_{4}, 140 \mathrm{mM}$ $\mathrm{NaCl}, 2.7 \mathrm{mM} \mathrm{KCl}$ ) containing $1 \mathrm{unit} / \mathrm{ml}$ rhodamine phalloidin (Molecular Probe) for $1 \mathrm{hr}$ at $25^{\circ} \mathrm{C}$. For staining of DNA, the fixed cells were incubated in PBS containing $0.05 \mu \mathrm{g} / \mathrm{ml}$ 4',6-deamidino-2-phenylindol (DAPI) for $30 \mathrm{~min}$ at $25^{\circ} \mathrm{C}$. The stained cells were observed and recorded under a vertical fluorescent microscope (Axiovert 135; Carl Zeiss) equipped with an Plan-Neo fluar $100 \times$ oil immersion objective (Carl Zeiss) and recorded by Argus-50 computer system. Fluorescence of GFP was observed using FITC filter cassette. In order to observe living cells, Ax 2 cells were suspended in MCM buffer at $22^{\circ} \mathrm{C}$ and plated on a 35 -mm glass-bottomed culture dish (MattTek Corp., Ashland MA), which was coated with poly-L-lysin, for $30 \mathrm{~min}$ before observation. Cell shapes were observed by Nomarski DIC system under the vertical microscope equipped with PlanApochromat $63 \times$ oil immersion objective (Carl Zeiss). In order to visualize distribution of GFP- 
actin in living cells, we used a computer-digitized real-time confocal laser scanning microscopy (INSIGHT ${ }_{\text {PLUS-IQ, Meri- }}$ dian Instruments, Far East K.K., Tokyo, Japan) equipped with a vertical microscope (IMT-2, Olympus, Tokyo, Japan), an Argon ion laser (500 m Watt), and an SPlanApo $100 \times$ oil immersion objective (Nikon Co., Tokyo, Japan). Since Ax2 cells are sensitive to the laser beam, we used 10\% ND filter at $20 \mathrm{~mW}$ power, and we exposed cells to the laser beam for $0.5 \mathrm{~s}$ at 10-s intervals. Under this condition, we can repetitively observed normal random walking of the cells for more than 30 min. Cell motility assay was performed at $22^{\circ} \mathrm{C}$ as previously described (27).

Electron Microscopic Observation. Cells grown on glass coverslips were fixed with $2.5 \%$ glutaraldehyde in PBS at $25^{\circ} \mathrm{C}$ for $30 \mathrm{~min}$. After dehydration through an ethanol series ( 5 min each of $30,50,80$, and $95 \%)$, then $100 \%$ ethanol $(3 \times 5$ min) and finally $100 \% t$-butanol $(3 \times 5 \mathrm{~min})$, the samples were chilled at $-20^{\circ} \mathrm{C}$ for $10 \mathrm{~min}$ before freeze drying. The samples coated with gold were examined with a scanning electron microscope (S4500, Hitachi, Tokyo Japan).

Protein Purification. D. discoideum myosin II was prepared as described (28). Its heavy chain was purified by excision of polyacrylamide gels after electrophoresis, and injected into virgin female Japan white rabbits as described previously (24) in order to produce antiserum against MHC. Rabbit muscle actin was prepared as described (29) with some modifications (24). Cofilin was purified from $D$. discoideum as previously described (24). Myosin II and its heavy meromyosin (HMM) were prepared from pig cheek muscle as described (30). Rabbit skeletal myosin subfragment-1 (S-1) was purchased from Sigma Co. (St. Louis, MO). The (His) 6 -tagged GFP-actin was prepared from Ax 2 cells carrying pHGACT as follows. The transformed cells were grown on 9-cm Petridishes in HL5 medium containing $10 \mu \mathrm{g} / \mathrm{ml}$ neomycin at a density of $2 \times 10^{7}$ cells $/$ dish. About $1 \times 10^{9}$ cells were collected and further grown in 500-ml suspension culture for $48 \mathrm{hr}$ at $25^{\circ} \mathrm{C}$, and harvested by centrifugation at $700 \mathrm{~g}$ for $5 \mathrm{~min}$ at $4^{\circ} \mathrm{C}$. The pellet was suspended in $100 \mathrm{ml}$ of $10 \mathrm{mM}$ Tris-Cl (pH 8.0), and centrifuged at $700 \mathrm{~g}$ for $5 \mathrm{~min}$ at $4^{\circ} \mathrm{C}$. The pellet ( $3.5 \mathrm{ml}$ in wet volume) was re-suspended in $35 \mathrm{ml}$ of $10 \mathrm{mM}$ Tris- $\mathrm{Cl}(\mathrm{pH} 8.0)$ containing protease inhibitors ( $1 \mathrm{mM}$ phenylmethylsulfonyl fluoride, $10 \mu \mathrm{g} / \mathrm{ml}$ leupeptin, and $1 \%$ aprotinin). The suspension was sonicated four times using a Branson Sonifier for 10 seconds at range 4 . The disruption of cells was confirmed microscopically. The extracts were clarified by ultracentrifugation at $100,000 \mathrm{~g}$ for $30 \mathrm{~min}$. The crude extracts $(36 \mathrm{ml})$ were adjusted to $500 \mathrm{mM} \mathrm{NaCl}$, and mixed with His - Bind Metal chelation resin which immobilized $\mathrm{Ni}^{2+}(1 \mathrm{ml}$ in wet volume; Novagen, Madison, WI) for 1 hour at $4{ }^{\circ} \mathrm{C}$ with occasional shaking. The His $\cdot$ Bind resin was collected as precipitates by centrifugation at $1,000 \mathrm{~g}$ for $1 \mathrm{~min}$, and washed four-times with $20 \mathrm{ml}$ of $10 \mathrm{mM}$ Tris-Cl (pH 8.0), 10 $\mathrm{mM}$ imidazole, and $500 \mathrm{mM} \mathrm{NaCl}$ by centrifugation. The resin was packed in a tube $(8 \mathrm{~mm} \times 300 \mathrm{~mm})$ and adsorbed proteins were eluted by a linear gradient of imidazole from
10 to $200 \mathrm{mM}$ in $5 \mathrm{ml}$ of $10 \mathrm{mM}$ Tris- $\mathrm{Cl}(\mathrm{pH} 8.0)$ and 500 $\mathrm{mM} \mathrm{NaCl}$. Elution of green solution containing (His) $)_{6}$-tagged GFP-actin was easily visible to the naked eye. (His) ${ }_{6}$-tagged GFP-actin was eluted with approximately $60 \mathrm{mM}$ imidazole. The elute was adjusted to $0.1 \mathrm{mM} \mathrm{CaCl}_{2}, 0.1 \mathrm{mM}$ dithiothreitol, and $0.2 \mathrm{mM}$ ATP, and dialyzed against depolymerizing buffer $\left(0.1 \mathrm{mM} \mathrm{CaCl}_{2}, 0.1 \mathrm{mM}\right.$ dithiothreitol, $0.2 \mathrm{mM}$ ATP, $2 \mathrm{mM}$ Hepes ( $\mathrm{pH} 7.8$ ), and $0.01 \% \mathrm{NaN}_{3}$ ) for $48 \mathrm{hr}$ at $4^{\circ} \mathrm{C}$. After centrifugation at $100,000 \mathrm{~g}$ for $20 \mathrm{~min}$, the supernatant was collected as a semi-purified GFP-actin fraction. The fraction $(600 \mu \mathrm{l})$ was adjusted to polymerizing condition by adding $60 \mu \mathrm{l}$ of $10 \times \mathrm{FB}(100 \mathrm{mM}$ Mes (pH 6.9), $10 \mathrm{mM}$ EGTA, 5 $\mathrm{mM}$ ATP, $10 \mathrm{mM} \mathrm{MgCl}$, and $500 \mathrm{mM} \mathrm{KCl}$ ). After incubation at $25^{\circ} \mathrm{C}$ for $3 \mathrm{hr}$, the fraction was centrifuged at 100,000 $\mathrm{g}$ for $30 \mathrm{~min}$, and the resultant green precipitates containing (His) ${ }_{6}$-tagged GFP-actin were collected. The precipitates were re-suspended with the depolymerizing buffer and dialyzed against the buffer for $72 \mathrm{hr}$ at $4^{\circ} \mathrm{C}$. The dialysate was clarified by centrifugation at $100,000 \mathrm{~g}$ for $30 \mathrm{~min}$, and the supernatant was collected as purified (His) 6 -tagged GFP-actin fraction for biochemical experiments. The purity was more than $95 \%$ as determined by gel electrophoresis.

Biochemical Characterization. Protein concentrations were determined by Bio-Rad Protein Assay System (Bio-Rad Laboratories, Richmond, CA) with goat $\gamma$-globulin as a standard. Sodium dodecyl sulfate-polyacrylamide gel electrophoresis (SDS-PAGE) was carried out according to the method of Laemmli (31) with 10-20\% gradient gel, Multigel 10/20 (Daiichi Pure Chemicals Co., Tokyo, Japan). Molecular weight

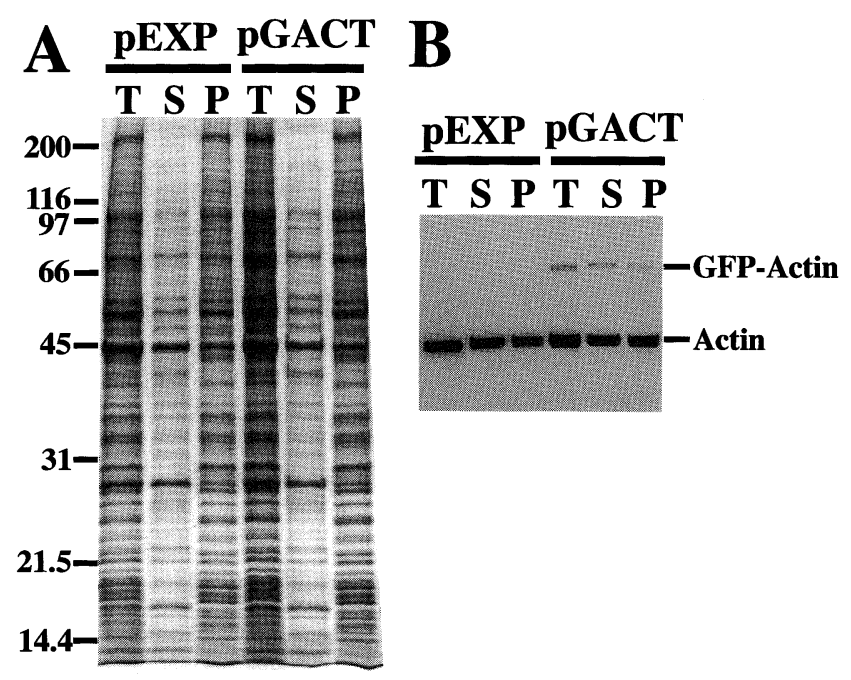

Fig. 1. Protein composition of control and GFP-actin expressing cells. (A) CBB staining of subcellular fractions after SDS-PAGE. (B) Western blotting of the fractions with anti-actin antibody. Total protein fractions (T) were prepared from control cells (pEXP) and GFPactin expression cells (pGACT) as described in Materials and Methods. The fractions were further fractionated by ultracentrifugation into supernatants $(\mathrm{S})$ and precipitates $(\mathrm{P})$. Molecular weights of marker proteins are indicated on the left side in thousands. 
markers for SDS-PAGE were purchased from Bio-Rad Laboratories (Hercules, CA); myosin $(200 \mathrm{kDa}), \beta$-galactosidase $(116 \mathrm{kDa})$, phosphorylase $\mathrm{b}(97 \mathrm{kDa})$, bovine serum albumin $(66 \mathrm{kDa})$, ovalbumin $(45 \mathrm{kDa})$, carbonic anhydrase $(31 \mathrm{kDa})$, trypsin inhibitor $(21.5 \mathrm{kDa})$, and lysozyme $(14.4 \mathrm{kDa})$. Gels were stained by Coomassie Brilliant Blue (CBB) R-250. Western blotting was performed as previously reported (Towbin et al., 1979) with some modifications (Aizawa et al., 1996) using a mouse anti-actin monoclonal antibody (clone C4; ICN Biomedicals Ins., Costa Mesa, CA) as the first antibody. Subcellular fractionation and analysis of protein compositions were performed as previously described (Aizawa et al., 1996). Briefly, transformed cells $\left(2 \times 10^{7}\right.$ cells) were grown on a $9-\mathrm{cm}$ dish. After incubation for $1 \mathrm{hr}$ at $22^{\circ} \mathrm{C}$ in MCM buffer (20 $\mathrm{mM}$ Mes (pH 6.85), $0.2 \mathrm{mM} \mathrm{CaCl}, 2 \mathrm{mM} \mathrm{MgCl}$ ), cells were lysed by $0.5 \mathrm{ml}$ of lysis buffer (20 mM Mes, $15 \mathrm{mM} \mathrm{KCl}, 2 \mathrm{mM}$ $\mathrm{MgCl}_{2}, 5 \mathrm{mM}$ EGTA, $1 \mathrm{mM}$ dithiothreitol, $0.5 \% \mathrm{NP}-40$, the protease inhibitors, $\mathrm{pH} 6.85$ ) at $22^{\circ} \mathrm{C}$ for $5 \mathrm{~min}$ on the dish. The lysate was collected by a cell scraper as the total fraction,

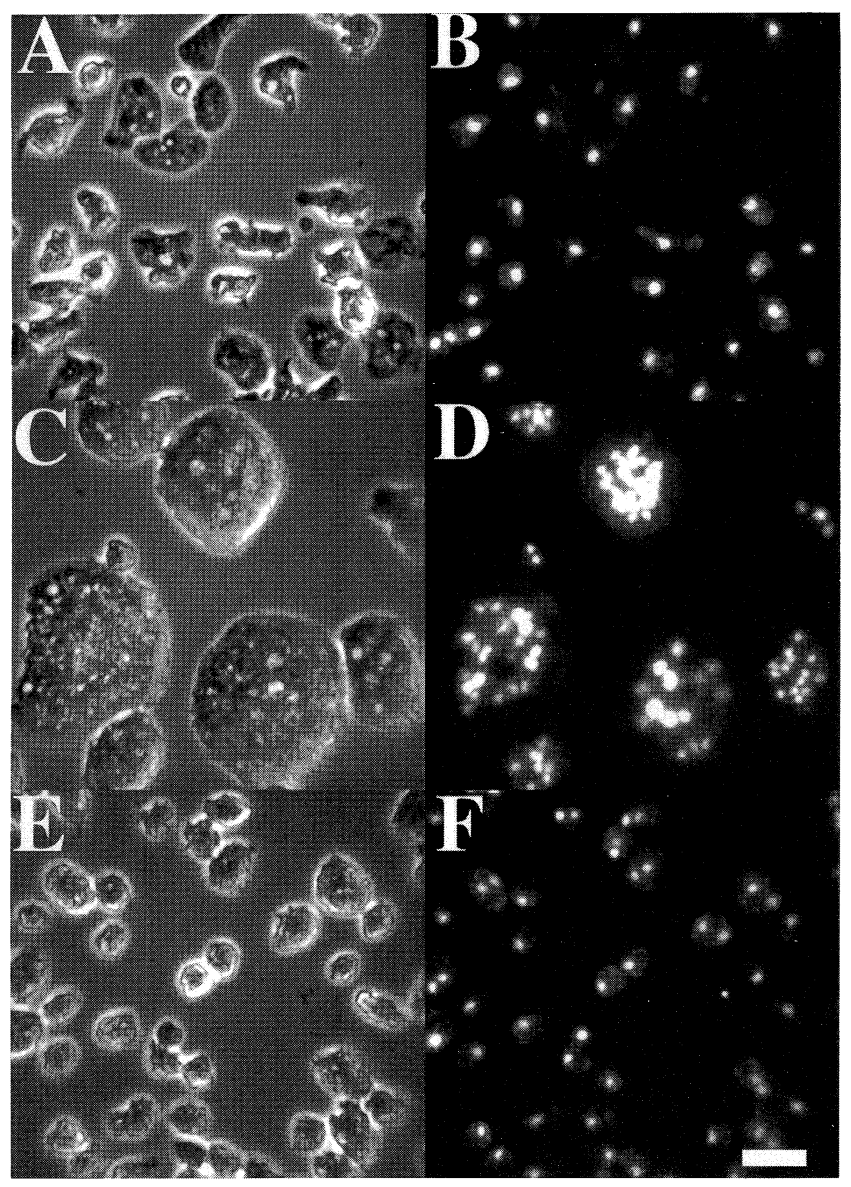

Fig. 2. Effect of GFP-actin on cytokinesis. Cells expressing GFP (A and $\mathrm{B}$ ) or GFP-actin (C, D, E, and F) were grown in suspension (A, $\mathrm{B}, \mathrm{C}$, and $\mathrm{D})$ or on the dish (E and F). Cells were re-suspended in MCM and placed on cover glasses for $10 \mathrm{~min}$ before fixation. (A, C, and E) Phase microscopy. (B, D, and F) DAPI staining. Bar, $20 \mu \mathrm{m}$.

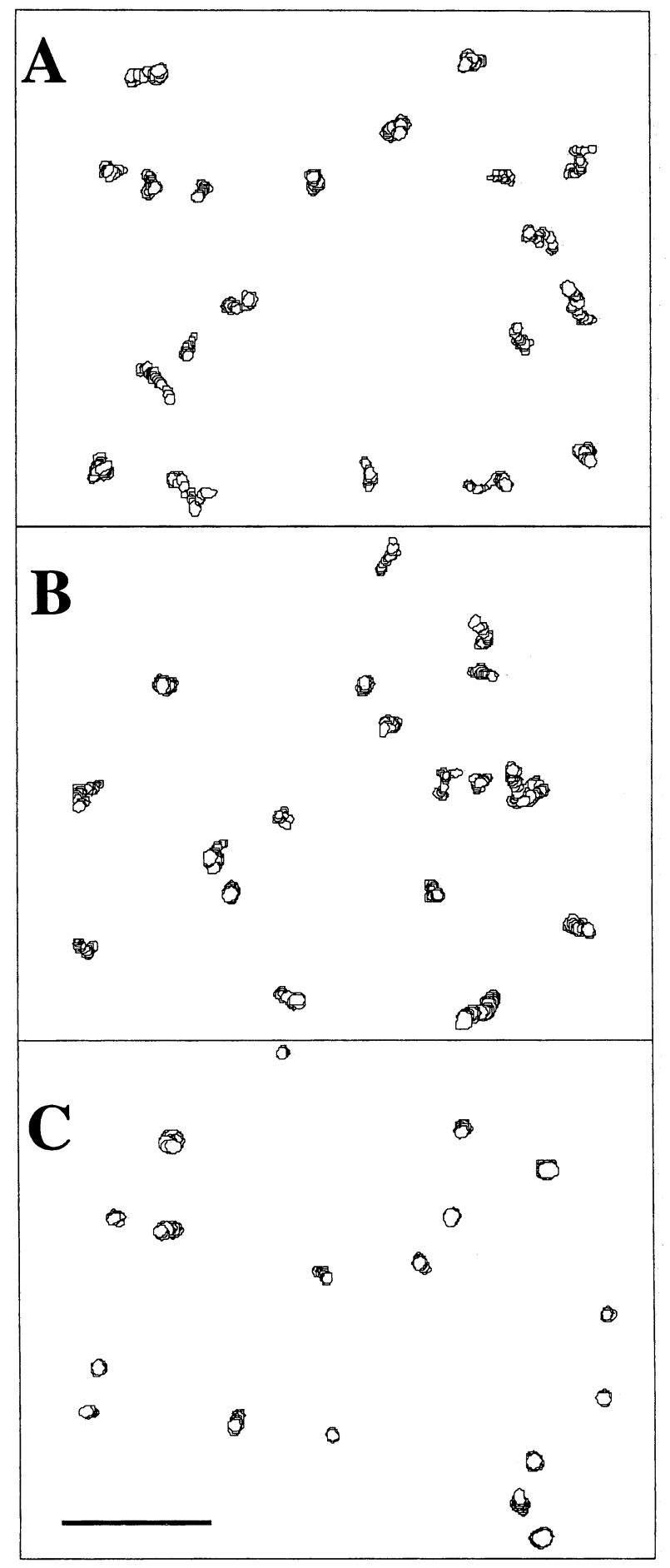

Fig. 3. Effect of GFP-actin on cell motility. Cells were placed on a glass coverslip for $1 \mathrm{hr}$ in MCM. Cell movement was automatically analyzed using computer program DIAS from serial images of cells. We represented one example among computer-digitized movies of control (A), GFP expressing (B), and GFP-actin expressing (C) cell movements at 1 -min intervals for $20 \mathrm{~min}$. Bar, $150 \mu \mathrm{m}$. 
and centrifuged at $400,000 \times \mathrm{g}$ for $30 \mathrm{~min}$ to collect supernatant and precipitate fractions separately. Protein compositions of each fraction were analyzed by SDS-PAGE. Sliding assay for actin filaments was performed as described (32). Rhodamine-phalloidin labeled filaments were observed under a fluorescence microscope (Axiophoto; Carl Zeiss, Oberkochen, Germany) equipped with an Plan-Neo fluar $100 \times$ oil immersion objective (Carl Zeiss). Original microscopic images detected by a SIT camera (C2400-08; Hamamatsu Photonics, Shizuoka, Japan) were enhanced and averaged by Argus-50 image processor (Hamamatsu Photonics), and recorded on an $8 \mathrm{~mm}$ video recorder (Sony, Tokyo, Japan). Mean speeds of actin filaments during 30-s observation were automatically calculated using computer program DIAS (Soltech Ins., Oakdale, CA) from the recorded video tapes. In this system, we could detect the sliding of individual actin filaments which
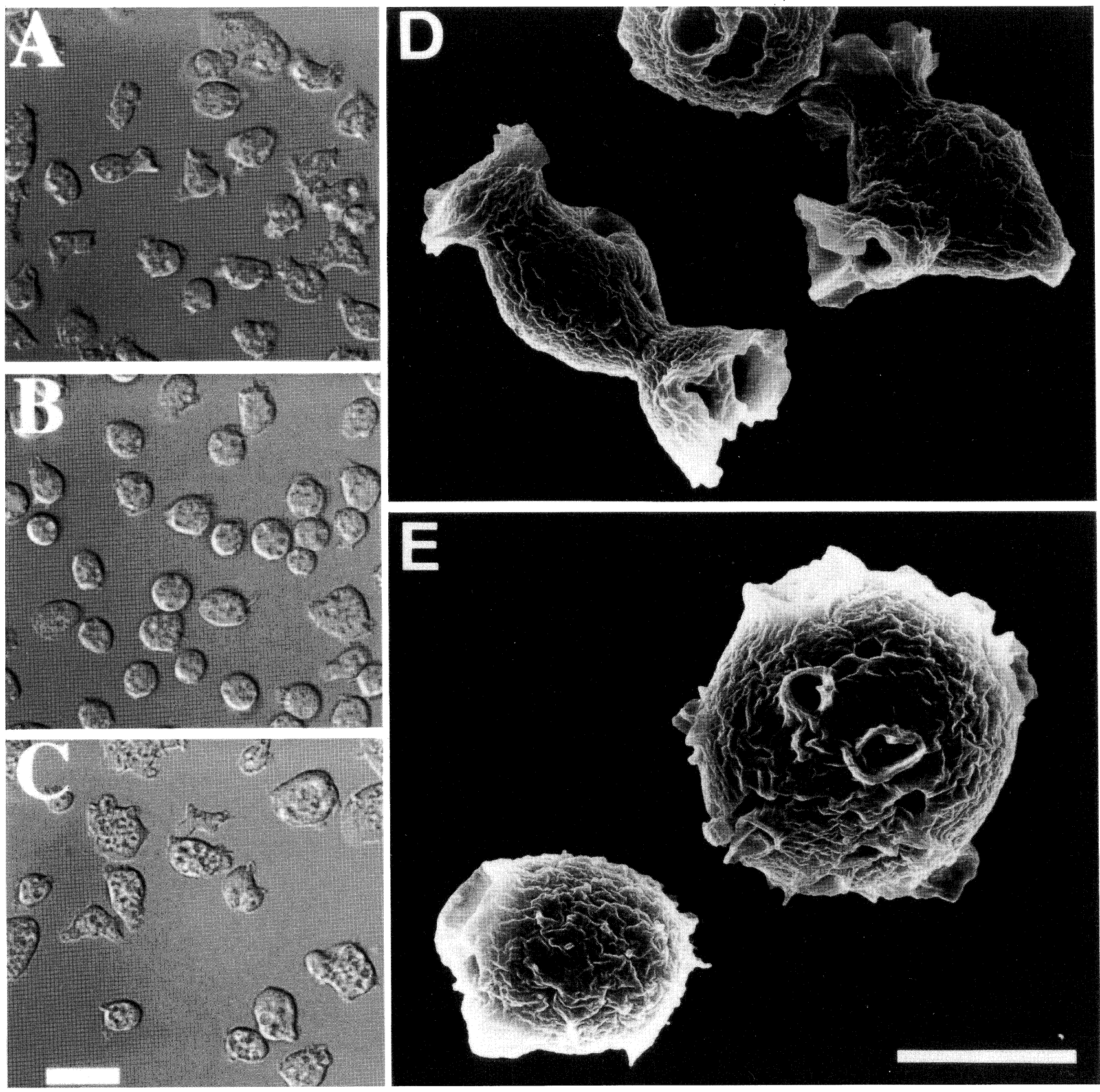

Fig. 4. Effect of GFP-actin on cell morphology. Cells expressing GFP (A and D), GFP-actin (B and E) or lacking myosin-II heavy chain (C) were grown on dish. (A, B, and C) Nomalski DIC microscopy of living cells. (D and E) Scanning electron microscopy of fixed cells. Bars in (C) and (E) are $20 \mu \mathrm{m}$ and $5 \mu \mathrm{m}$, respectively. 
were sliding at more than $0.02 \mu \mathrm{m} / \mathrm{sec}$.

\section{RESULTS}

Expression of GFP-actin in D. discoideum. We constructed three vectors, that is, a control vector ( $\mathrm{pEXP}$ ), a vector for expression of GFP (pGFP), and a vector for expression of GFP-actin (pGACT) in $D$. discoide$u m$. GFP-actin is a chimeric protein consisting of amino-terminal GFP moiety and carboxy-terminal actin moiety without any spacer sequences between the two. After electroporation, transformed Ax 2 cells were selected by neomycin. Every electroporation repeatedly yielded about a hundred colonies, and we used the mixed clones within 3 weeks for all experiments described in this paper. Protein compositions of transformed cells containing pEXP or pGACT were analyzed by SDS-PAGE (Fig. 1A). Total cell homogenates were centrifuged, and protein compositions of the resultant supernatant and precipitate fractions were also analyzed (Fig. 1A). We did not detect any significant difference between the protein compositions of transformed cells carrying pEXP and pGACT. Western blot analysis revealed the expression of a $70-\mathrm{kDa}$ protein stained with anti-actin antibody in the latter cells as well as the endogenous $42-\mathrm{kDa}$ actin molecule (Fig. 1B). Since molecular mass of $70-\mathrm{kDa}$ protein is well con-
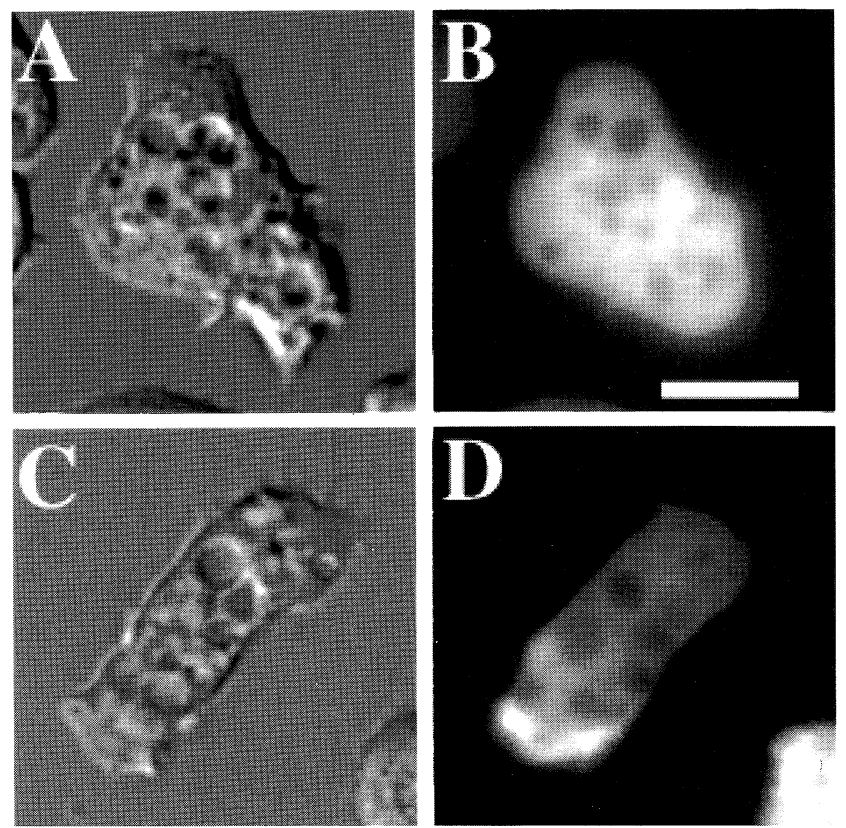

Fig. 5. Effect of myosin II elimination on the rounding up of GFPactin expressing cells. MHC-null mutant was transformed with pGFP (A and B) or pGACT (C and D). Living cells were sequentially observed by Nomalski DIC microscopy (A and C) and fluorescent microscopy (B and D) at $10 \mathrm{sec}$ intervals. Bar, $10 \mu \mathrm{m}$. sistent with calculated molecular mass $(69,026)$ of the GFP-actin fusion protein, we concluded that the 70$\mathrm{kDa}$ actin is GFP-actin. The amount of GFP-actin is about $3 \%(\mathrm{~mol} / \mathrm{mol})$ of total actin in the transformed cells (Fig. 1B). About a half of the GFP-actin was collected in the precipitate fraction by centrifugation as the authentic actin (Fig. 1B).
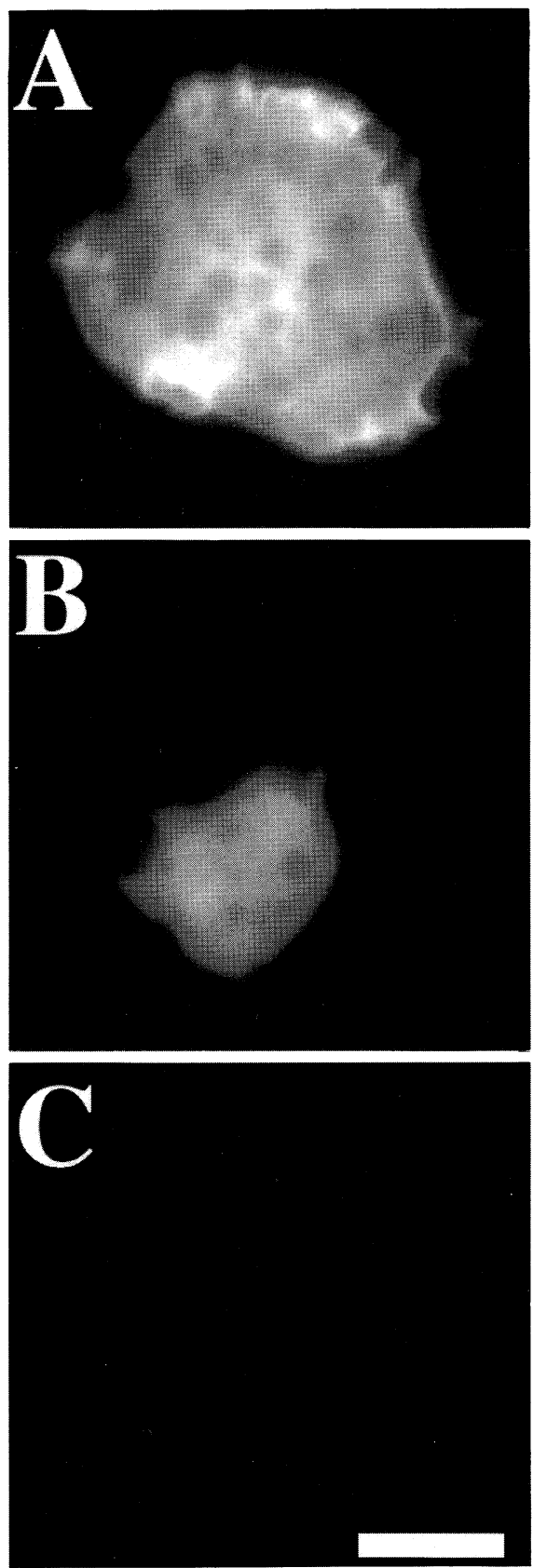

Fig. 6. Intracellular localization of GFP-actin in a living cell. Cells expressing GFP-actin (A), GFP (B), and control (C) were placed on a glass coverslip in MCM buffer for $1 \mathrm{hr}$ before observation by fluorescence microscope. Bar, $10 \mu \mathrm{m}$. 
Phenotypes of GFP-actin Expressing Cells. GFPactin expressing cells grew slightly slower than GFP expressing cells on dish (data not shown). On dish culture, $20 \%$ of GFP-actin expressing cells contained plural nu-

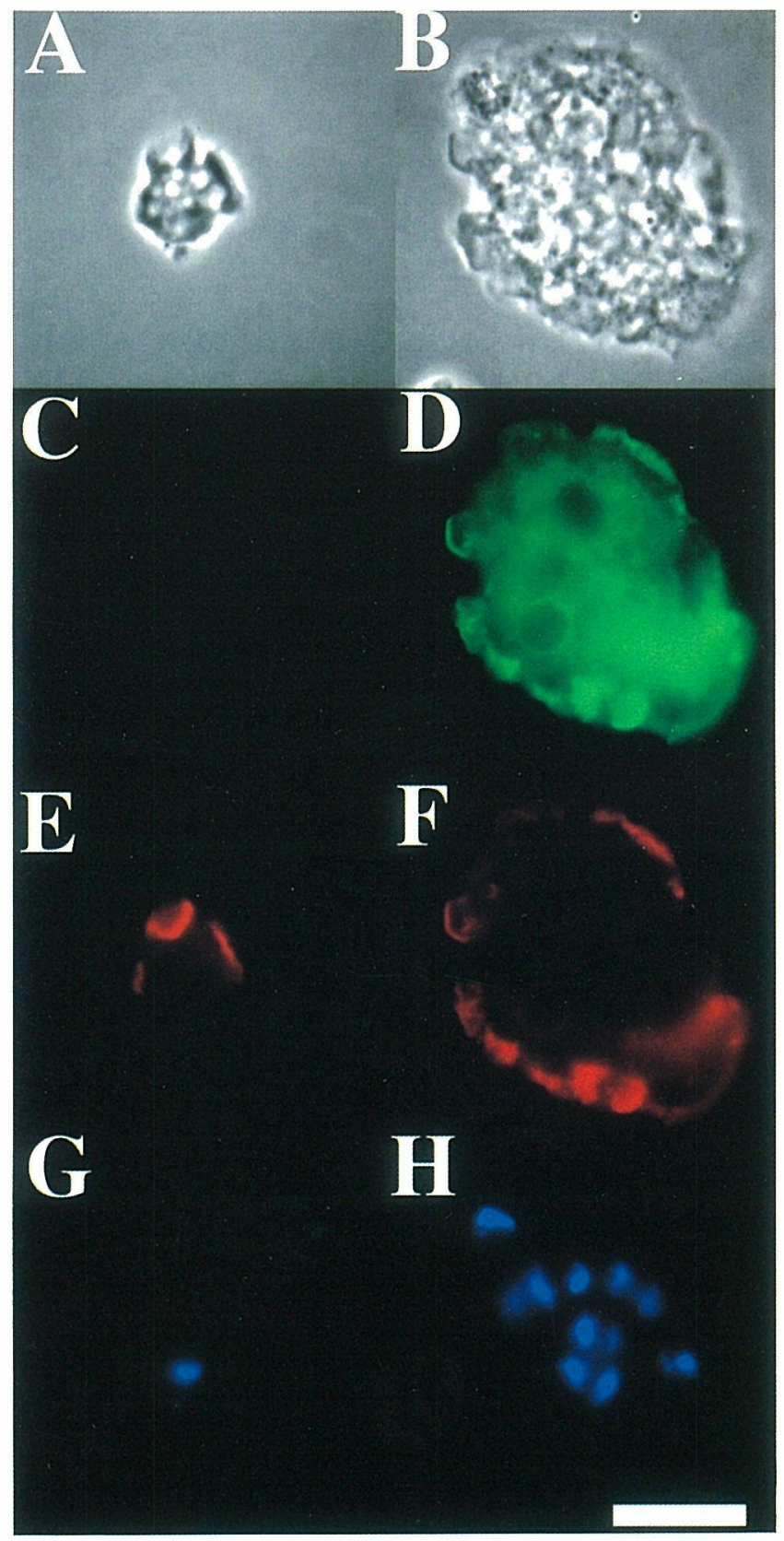

Fig. 7. Co-localization of GFP-actin and actin filaments in a fixed cell. Cells containing the control vector (A, C, E, and G) or the GFPactin expression vector (B, D, F, and $\mathrm{H}$ ) were placed on a glass coverslip in MCM buffer for $1 \mathrm{hr}$ before fixation. Cells were observed by phase microscopy (A and B) and fluorescence microscope for GFP-actin $(\mathrm{C}$ and $\mathrm{D})$. The fixed cells were also stained with rhodamine phalloidin ( $\mathrm{E}$ and $\mathrm{F})$ and DAPI $(\mathrm{G}$ and $\mathrm{H})$ to visualize actin filaments and nuclei, respectively. Bar, $10 \mu \mathrm{m}$. clei (Fig. 2E and F), while less than $2 \%$ of GFP expressing cells were multinucleated (data not shown). In suspension culture, almost all the GFP-actin expressing cells failed to divide and formed multinucleated giant cells (Fig. 2C and D), while 98\% of GFP expressing cells were mononucleated (Fig. 2A and B). Proliferating control cells, GFP expressing cells, and GFP-actin expressing cells walked randomly at $1.74 \pm 0.65 \mu \mathrm{m} / \mathrm{min}$ $(\mathrm{n}=63), 1.54 \pm 0.55 \mu \mathrm{m} / \mathrm{min}(\mathrm{n}=49)$, and $0.81 \pm 0.42$ $\mu \mathrm{m} / \mathrm{min}(\mathrm{n}=51)$, respectively (Fig. 3). GFP-actin expressing cells rounded up and had spherical morphology, while GFP expressing control cells and MHC disruptant cells spread well on dish with elongated cell shapes (Fig. 4A-C). The GFP-actin expressing cells developed smaller crown-like protrusions from cell surfaces than GFP expressing cells (Fig. 4D and E). Genetic elimination of MHC suppressed the rounding up of GFP-actin expressing cells (Fig. 5A and C). This indicated that myosin II is necessary for rounding up of the GFP-actin expressing cells. In the living cell without MHC, GFP localized diffusely in cytoplasm except for vesicular structures (Fig. 5B). On the other hand, GFPactin strongly accumulated at leading edge of the living MHC-null cell. GFP-actin also localized diffusely in cytoplasm except for the vesicular structures in the MHC-null cell (Fig. 5D). Under starvation stress,

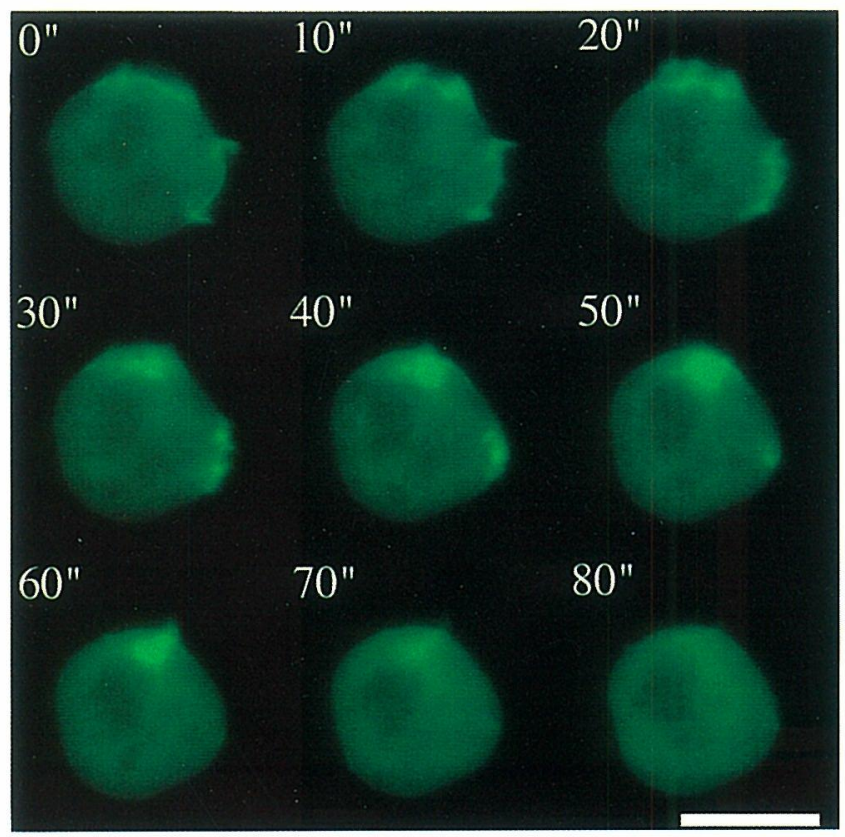

Fig. 8. Real-time observation of GFP-actin in a living cell. The fluorescence of GFP-actin in a living cell on a glass coverslip was observed under razor scanning confocal microscopy at 10-s intervals for $300 \mathrm{~s}$. During the time period, we observed that four crowns appeared and disappeared in this cell. Here we represented 9 serial pictures among them. Bar, $10 \mu \mathrm{m}$. 
intracellular concentration of GFP-actin decreased within $8 \mathrm{hr}$, and GFP-actin expressing cells completed spore formation within $36 \mathrm{hr}$ on a filter (data not shown).

Intracellular Distribution of GFP-actin. In a living Ax2 cell, GFP-actin accumulated at the cortical region just under the plasma membranes (Fig. 6A). Among the cell cortex, GFP-actin was highly concentrated in crown-like protrusions (see Fig. 4E). Some of the GFPactin also localized diffusely in the cytosol except for vesicular-like structures. By contrast, we found that almost all the GFP localized diffusely in the cytosol except for vesicular-like structures (Fig. 6B). Under our experimental condition, we did not detect any fluorescence in transfectants containing the control vector (Fig. 6C). In a fixed control cell, fine networks of actin filaments were detected all over the cell cortex, and
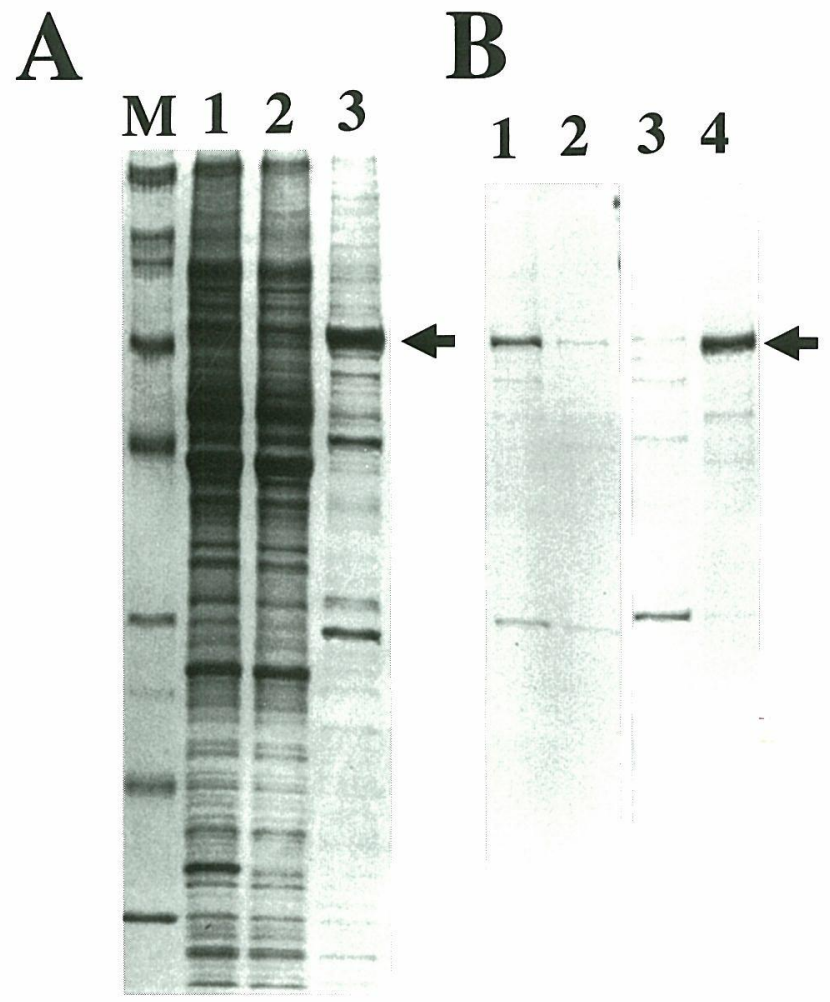

Fig. 9. Purification of GFP-actin. (A) Affinity-purification of GFPactin. Crude extracts were prepared from Ax2 cells expressing (His) ${ }_{6}^{-}$ tagged GFP-actin. The extracts were applied onto $\mathrm{Ni}^{2+}$-immobilized His - Bind resin, and absorbed materials were eluted by a linear gradient of imidazole. Lane 1; crude extract fraction, lane 2; unbound flow through fraction, lane 3; eluted GFP-actin fraction, M; marker proteins. (B) Sedimentation of GFP-actin by ultracentrifugation. Affinity-purified GFP-actin fraction was dialyzed against the depolymerizing buffer. With (lanes 3 and 4 ) or without (lanes 1 and 2) the addition of $1 / 10$-vol of $10 \times \mathrm{FB}$, the dialysate was ultracentrifuged. The supernatants (lanes 1 and 3) and precipitates (lanes 2 and 4) were collected. All the fractions were analyzed by SDS-PAGE and stained with CBB. The arrows indicate positions of GFP-actin. thick bundles of actin filaments were constructed on the margin of leading edge of crown-like protrusions (Fig. 7E). In the GFP-actin expressing giant cells, we found a cortical fine actin networks and thick bundles of actin filaments on the margin of the leading edge of crownlike protrusions (Fig. 7F). GFP-actin co-localized with all of these actin filament architectures in the cell (Fig. $7 \mathrm{D}$ and $\mathrm{F}$ ). We sometimes observed the accumulation of GFP-actin and actin filaments just at the periphery of large vacuolar structures (Fig. 7D and F). GFP-actin also localized in cytoplasm diffusely, presumably as monomers (Fig. 7D). Real-time observation of GFP-actin in a living cell revealed that the GFP-actin filaments strongly accumulated in the crown-like protrusions (Fig. 8). As the crown closed and retracted to cell body,
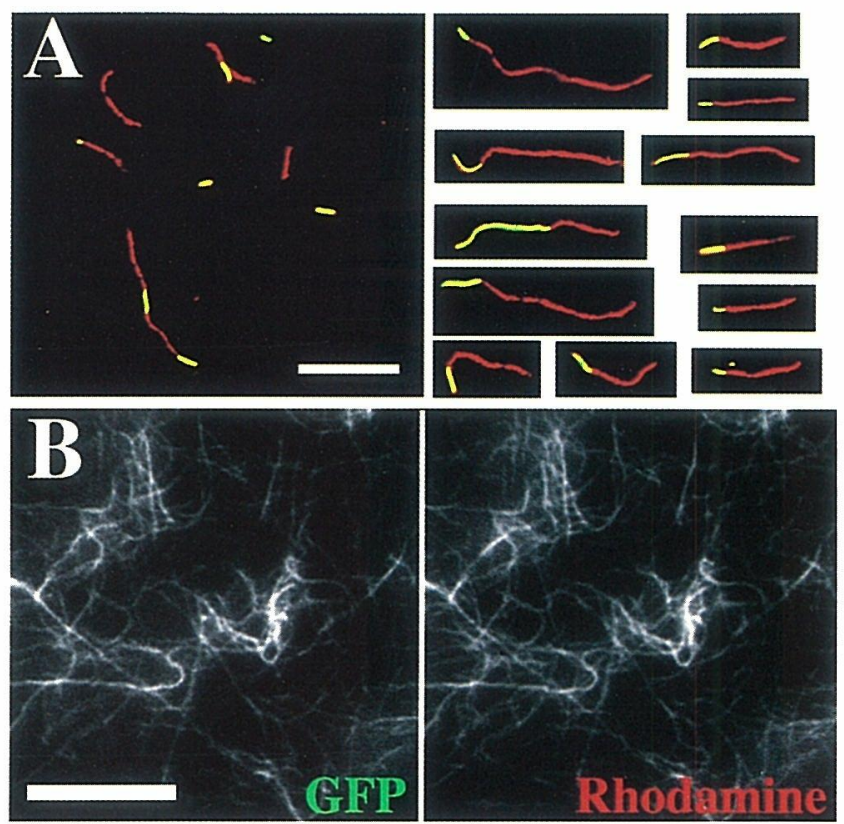

Fig. 10. Filaments of polymerized GFP-actin and actin. (A) Elongation of actin filaments on the ends of GFP-actin filaments. Purified GFP-actin $(3 \mu \mathrm{M})$ was polymerized by addition of $1 / 10$-vol $10 \times \mathrm{FB}$ and incubated at $25^{\circ} \mathrm{C}$ for $3 \mathrm{hr}$. The GFP-actin solution $(2 \mu \mathrm{l})$ was mixed sequentially with the depolymerizing buffer $(15 \mu \mathrm{l}), 20 \mu \mathrm{M}$ actin $(1 \mu \mathrm{l})$, and $10 \times \mathrm{FB}(2 \mu \mathrm{l})$, and incubated at $25^{\circ} \mathrm{C}$ for $1 \mathrm{hr}$. For staining actin filaments, the solution was mixed with $1 \mu \mathrm{M}$ rhodamine-phalloidin $(20 \mu \mathrm{l})$ in $1 \times \mathrm{FB}$ for $1 \mathrm{hr}$. Just before observation, the solution $(1 \mu \mathrm{l})$ was diluted with $1 \times \mathrm{FB}(50 \mu \mathrm{l})$, and an aliquot $(3 \mu \mathrm{l})$ of the diluted sample was observed on an 18-mm square glass coverslip under fluorescent microscopy. Fluorescent images of GFP (green) and rhodamine (red) were superimposed. (B) Co-polymerization of GFP-actin and actin. GFP-actin (final $1.5 \mu \mathrm{M}$ ) and actin (final $1.5 \mu \mathrm{M}$ ) were mixed in $1 \times \mathrm{FB}$ and incubated at $25^{\circ} \mathrm{C}$ for $4 \mathrm{hr}$. The mixture $(40 \mu \mathrm{l})$ was mixed with $2 \mu \mathrm{M}$ rhodamine-phalloidin $(40 \mu \mathrm{l})$, and incubated for $1 \mathrm{hr}$. After 10-times dilution by $1 \times \mathrm{FB}$, an aliquot $(3 \mu \mathrm{l})$ of the mixture was observed on an $18-\mathrm{mm}$ square glass coverslip under fluorescent microscopy. Fluorescent images of GFP and rhodamine were presented separately. Bars, $10 \mu \mathrm{m}$. 
the accumulated GFP-actin diffused uniformly into cytoplasm (Fig. 8). This intracellular behavior of GFPactin molecules is similar to that of fluorescently labeled actin microinjected in $D$. discoideum cells, although crown-like protrusions appeared to move slower in the GFP-actin expressing cells than in the microinjected cells (33).

Purification and Biochemical Characterization of GFP-actin. In order to purify GFP-actin, we expressed (His) ${ }_{6}$-tagged GFP-actin in $D$. discoideum cells by a vector pHGACT. The GFP-actin was affinity-purified by $\mathrm{Ni}^{2+}$-resin column chromatography from extracts of the transformed cells. The affinity-purified fraction contained a $70-\mathrm{kDa}$ protein (Fig. 9A), which reacted with anti-actin antibody (data not shown). After incubation of the purified fraction under the condition favorable for actin depolymerization, more than $90 \%$ of the 70 $\mathrm{kDa}$ GFP-actin was recovered in the supernatant by centrifugation (Fig. 9B). By contrast, more than $95 \%$ of GFP-actin was precipitated by centrifugation after incubation of the purified fraction under the condition favorable for actin polymerization (Fig. 9B). From densitometric analysis of the gel, we calculated the critical concentration of GFP-actin for polymerization to be about $0.08 \mu \mathrm{M}$, which is almost identical to that of authentic actin. The precipitated GFP-actin was recovered in the supernatant by centrifugation after post-incubation under the depolymerizing condition (data not shown). This supernatant was used as purified GFP-actin fraction in the following biochemical experiments. Fluorescence microscopic observation revealed that purified GFP-actin assembled into filamentous structures under the polymerizing condition (Fig. 10A and 12B). GFP-actin filaments were able to bind to rhodamineconjugated phalloidin (Fig. 10A and 12B). Electron mi-

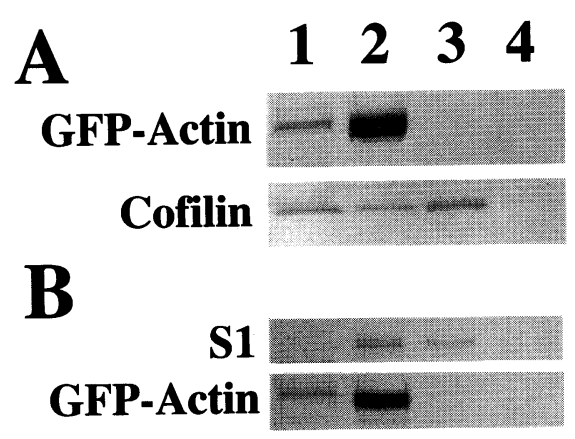

Fig. 11. Co-sedimentation of cofilin and S-1 with GFP-actin filaments. (A) Co-sedimentation of cofilin. (B) Co-sedimentation of S-1. Cofilin (final $3 \mu \mathrm{M}$ ) or S-1 (final $1 \mu \mathrm{M}$ ) was incubated at $25^{\circ} \mathrm{C}$ for $2 \mathrm{hr}$ in $1 \times \mathrm{FB}$, which contains $0.5 \mathrm{mM}$ ATP, in the presence (lanes 1 and 2) or absence (lanes 3 and 4 ) of GFP-actin $(3 \mu \mathrm{M})$. By centrifugation at $400,000 \mathrm{~g}$ for $30 \mathrm{~min}$, supernatants (lanes 1 and 3 ) and precipitates (lanes 2 and 4) were collected. Samples were analyzed by SDS-PAGE and stained with CBB. croscopic observation of negatively stained GFP-actin filaments showed filamentous polymers which were 8 $\mathrm{nm}$ in diameter (data not shown). Addition of monomeric actin to GFP-actin filaments caused almost unidirectional elongation of the filaments under the conditions employed (Fig. 10A). When a mixture of GFP-actin monomer $(50 \%)$ and authentic actin monomer $(50 \%)$ was incubated under the polymerizing condition, GFP-actin and actin co-polymerized uniformly into filaments (Fig. 10B). Cofilin, an actin-binding protein, and myosin subfragment-1 (S-1) co-sedimented with GFPactin filaments in the presence of ATP (Fig. 11). GFPactin filaments bound to HMM-coated coverglass surfaces in the absence of ATP (Fig. 12). Authentic actin filaments on the HMM-coated coverglass surfaces
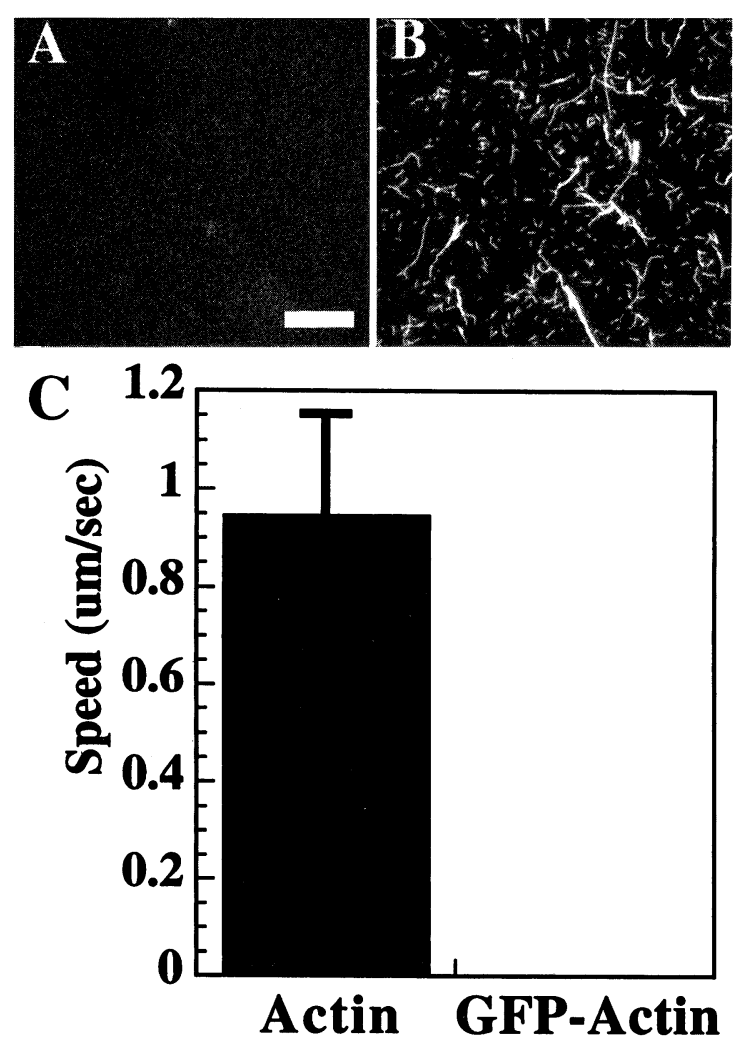

Fig. 12. Sliding assay of GFP-actin filaments on HMM-coated glass surfaces. (A) No binding of GFP-actin filaments on an uncoated cover glass surface in the absence of ATP. (B) Binding of GFP-actin filaments on a HMM-coated glass surface in the absence of ATP. (C) Mean velocity of sliding on HMM-coated glass surfaces of actin filaments and GFP-actin filaments in the presence of $2 \mathrm{mM}$ ATP. Purified actin $(6 \mu \mathrm{M})$ or GFP-actin $(6 \mu \mathrm{M})$ was polymerized in $1 \times \mathrm{FB}$ at $25^{\circ} \mathrm{C}$ for $2 \mathrm{hr}$, and mixed with an equal volume of $6 \mu \mathrm{M}$ rhodaminephalloidin in $1 \times \mathrm{FB}$. The solutions $(4 \mu \mathrm{l})$ were further diluted with $100 \mu \mathrm{l}$ of $24 \mathrm{mM} \mathrm{KCl}, 10 \mathrm{mM}$ Mes (pH 6.8), $4 \mathrm{mM} \mathrm{MgCl}, 1 \mathrm{mM}$ EGTA, $1 \mathrm{mM}$ DTT, $0.5 \mathrm{mg} / \mathrm{ml}$ bovine serum albumin, and perfused into a microchamber consisting of a slide glass, a cover glass, and $0.2-$ $\mathrm{mm}$ thick spacers. Filaments were visualized under a fluorescence microscope through rhodamine channel. Bar, $20 \mu \mathrm{m}$. 
moved at $0.95 \pm 0.20 \mu \mathrm{m} / \mathrm{sec}(\mathrm{n}=14)$ by addition of ATP, while the GFP-actin filaments did not move at all $(n=53)$ (Fig. 12C). This result indicates that the GFPactin filaments formed rigor complexes with myosin heads even in the presence of ATP.

\section{DISCUSSION}

In our expression system, the concentration of GFPactin was only $3 \%$ of total actin in Dictyostelium cells. This trace amount of the expression, however, completely inhibited cytokinesis in suspension culture. The GFPactin expressing cells migrate slower than wild type cells and show almost spherical cell shape. The GFP-actin expressing cells were also unable to perform capping reaction induced by concanavaline A (data not shown). The expression of GFP, which was free from actin molecule, did not cause these abnormal phenotypes at all. This result indicated that GFP-actin dominantly affected actin functions in cells. Since cytokinesis, cell shape, locomotion, and capping reaction are all known to be regulated by actin-myosin II interaction (12-14), these abnormal phenotypes of GFP-actin expressing cells suggest that GFP-actin dominantly inhibits some of actin functions on myosin II in cells.

We clearly demonstrated that myosin II is necessary for rounding up of GFP-actin expressing cells. This genetical evidence indicated that GFP-actin dominantly affected actomyosin interaction in the cells. Myosin II is well known to slide on actin filaments in order to produce contraction power for cell shape change. Thus, we performed in vitro motility assay using GFP-actin filaments. We found that GFP-actin filaments completely associated with S-1 fragment and freezed on HMMcoated coverglass surface even in the presence of ATP. We also demonstrated that GFP-actin assembled into filaments in cells. In Ax2 cells, the molar concentration of MHC (ca. $1 \mathrm{mg} / \mathrm{ml}, 5 \mu \mathrm{M}$ ) is $2 \%$ of the total actin (ca. $12 \mathrm{mg} / \mathrm{ml}, 300 \mu \mathrm{M}$ ), which is comparable to that of GFP-actin. If one GFP-actin traps one myosin II head and never releases it, most myosin II molecules are expected to form a rigor complex with actin filaments in GFP-actin expressing cells. Since a single myosin II molecule contains two head regions, myosin II may artificially cross-link actin filaments in the GFP-actin expressing cells. Since myosin II molecules could be assembled into thick filaments, very large rigor complexes of actomyosin could be formed in the GFP-actin expressing cells. The formation of a cortical rigor complex of actomyosin may cause the cells round up. It is reported that azide-treatment makes cells to round up in a myosin IIdependent manner (14). The azide-treatment is known to deplete intracellular ATP (34). ATP depletion caused formation of rigor complex of actomyosin in vitro. These data might support the idea that the formation of rigor complex of actomyosin caused the cells to round up in the GFP-actin expressing cells.

How does the GFP-actin inhibit cytokinesis, cell movement, and capping reaction? The rigor complex formation of GFP-actin and myosin II may fix the cells in a non-motile state, and inhibit cytokinesis and capping reaction. At present, however, we should also consider other possible dominant effects of GFP-actin on cytokinesis or cell movement. Even in the MHC-null cells, the expression of GFP-actin significantly increased the number of nucleus in a single cell on dish culture (data not shown). This result strongly suggests that GFP-actin also dominantly affected other functions of actin molecule than interaction with myosin II. It is well considered that GFP-actin filaments form rigor complex with various types of myosins including myosin I. It is also possible that GFP-actin dominantly inhibits some activities of actin binding proteins. As for cytokinesis, cell locomotion, and capping reaction, we can now conclude only that actin filaments are necessary for the three cell movements.

Acknowledgments. We would like to express our special thanks to Dr. R. Tsien, Dr. D. Knecht, and Dr. J. Spudich for generous gifts of a plasmid containing an S65T-GFP, a plasmid SC79, and a plasmid pBIG-myosin, respectively. We thank Dr. Y. Fukui for fruitful discussions on the phenotypes of GFP-actin expressing cells. We thank Dr. K. Umezono, Dr. S. Yuba, and Dr. Y. Yoneda for suggestions on GFP expression. We also thank Mr. T. Nagaoka and Mr. J. Ito for graphic assistance. We also thank Dr. K. Iida, Mr. K. Moriyama, Dr. Y. Minami, Dr. S. Matsumoto, Mrs. I. Ishii, Miss K. Kimura, and Miss M. Isohata for discussions and technical support. This work was supported in part by grants-in-aid from the Ministry of Education, Science, and Culture of Japan.

\section{REFERENCES}

1. Heath, J.P. and Holifield, B.F. 1991. Cell locomotion: new research tests old ideas on membrane and cytoskeletal flow. Cell Motil. Cytoskel., 18: 245-257.

2. Stossel, T.P. 1993. On the crawling of animal cells. Science, 260: 1086-1094.

3. COOPER, J.A. 1987. Effects of cytochalasin and phalloidin on actin. J. Cell Biol., 105: 1473-1478.

4. Forscher, P. and SMIth, S.J. 1988. Actions of cytochalasins on the organization of actin filaments and microtubules in a neuronal growth cone. J. Cell Biol., 107: 1505-1516.

5. KabSCH, W. and VANDeKerCKhove, J. 1992. Structure and function of actin. Annu. Rev. Biophys. Biomol. Struct., 21: 4976.

6. BRetscher, A. 1991. Microfilament structure and function in the cortical cytoskeleton. Annu. Rev. Cell Biol., 7: 377-374.

7. Hartwig, J.H. and KwIATKOWSKI, D.J. 1991. Actin-binding proteins. Curr. Opin. Cell Biol., 3: 87-97.

8. Амоs, L.A. 1985. Structure of muscle filaments studied by electron microscopy. Annu. Rev. Biophys. Biophys. Chem., 14: 291-313.

9. Langanger, G., Moeremans, M., Daneels, G., Sobieszek, A., de Brabander, M., and DE MeY, J. 1986. The molecular or- 
ganization of myosin in stress fibers of cultured cells. J. Cell Biol., 102: 200-209.

10. Strome, S. 1993. Determination of cleavage planes. Cell, 72: 3-6.

11. MabUCHI, I. and OKUno, M. 1977. The effect of myosin antibody on the division of starfish blastomeres. J. Cell Biol., 74: 251-263.

12. Lozanne, A.D. and Spudich, J.A. 1987. Disruption of the Dictyostelium myosin heavy chain gene by homologous recombination. Science, 236: 1086-1090.

13. Wessels, D., Soll, D.R., Knecht, D., Loomis, W.F., Lozanne, A.D., and Spudich, J.A. 1988. Cell motility and chemotaxis in Dictyostelium amoeba lacking myosin heavy chain. Dev. Biol., 128: 164-177.

14. Pasternak, C., Spudich, J.A., and Elson, E.L. 1989. Capping of surface receptors and concomitant cortical tension are generated by conventional myosin. Nature, 341: 549-551.

15. Korn, E.D. and Hammer, J.A. 1990. Myosin I. Curr. Opin. Cell Biol., 2: 57-61.

16. Pollard, T.D., Doberstein, S.K., and Zot, H.G. 1991. Myosin-I. Annu. Rev. Physiol., 53: 653-681.

17. Cheney, R.E., RIley, M.A., and Mooseker, M.S. 1993. Phylogenetic analysis of the myosin superfamily. Cell Motil. Cytoskel., 24: 215-223.

18. Titus, M.A. 1993. Myosins. Curr. Opin. Cell Biol., 5: 77-81.

19. Yumura, S., Mori, H., and FukUi, Y. 1984. Localization of actin and myosin for the study of ameboid movement in Dictyostelium using improved immunofluorescence. J. Cell Biol., 99: 894-899.

20. Yumura, S. and Fukui, Y. 1985. Reversible cyclic AMP-dependent change in distribution of myosin thick filaments in Dictyostelium. Nature, 314: 194-196.

21. Fukui, Y., LynCh, T.J., BrZeSKa, H., and Korn, E.D. 1989. Myosin I is located at the leading edges of locomoting Dictyostelium amoeba. Nature, 341: 328-331.

22. Jung, G. and HAMMER, J.A. 1990. Generation and characterization of Dictyostelium cells deficient in a myosin I heavy chain isoform. J. Cell Biol., 110: 1955-1964.

23. Wessels, D., Murray, J.M., Jung, G., Hammer, J.A., and SolL, D.R. 1991. Myosin IB null mutants of Dictyostelium exhibit abnormalities in motility. Cell Motil. Cytoskel., 20: 301315 .
24. Aizawa, H., Sutoh, K., Tsubuki, S., Kawashima, S., IshiI, A., and YAHARA, I. 1995. Identification, characterization, and intracellular distribution of cofilin in Dictyostelium discoideum. J. Biol. Chem., 270: 109223-10932.

25. UYedA, T.Q., RUPPEL, K.M., and SPUDiCh, J.A. 1994. Enzymatic activities correlate with chimeric substitution at the actinbinding face of myosin. Nature, 368: 567-569.

26. SUтон, K. 1993. A transformation vector for Dictyostelium discoideum with a new selectable marker bsr. Plasmid, 30: 150154.

27. Aizawa, H., Sutoh, K., and Yahara, I. 1996. Overexpression of cofilin stimulates bundling of actin filaments, membrane ruffling, and cell movement in Dictyostelium. J. Cell Biol., 132: 335-344.

28. Clarke, M. and Spudich, J.A. 1974 . Biochemical and structural studies of actomyosin-like proteins from non-muscle cells. J. Mol. Biol., 86: 209-222.

29. SPUdich, J.A. and WATt, S. 1971. The regulation of rabbit skeletal muscle contraction. I. Biochemical studies of the interaction of the tropomyosin-toroponin complex with actin and the proteolytic fragments of myosin. J. Biol. Chem., 246: 48664871.

30. Margossian, S.S. and Lowey, S. 1982. Preparation of myosin and its subfragments. Methods in Enzymology, 85: 55-71.

31. LAEMmLI, U.K. 1970. Cleavage of structural proteins during the assembly of the head of bacteriophage T4. Nature, 227: $680-685$.

32. Kron, S.J., Toyoshima, Y.Y., Uyeda, T.Q.P., and Spudich, J.A. 1986. Assays for actin sliding movement over myosin coated surfaces. Methods in Enzymology, 196: 399-416.

33. Yumura, S. 1996. Spatial distribution of fluorescently labeled actin in living Dictyostelium amoeba. Cell Struc. Funct., 21: 189-197.

34. Persson, R., Ahtstrom, E., and Fries, E. 1988. Differential arrest of secretory protein transport in cultured rat hepatocytes by azide treatment. J. Cell Biol., 107: 2503-2510.

(Received for publication, February 2, 1997

and in revised form, March 25, 1997) 